\title{
Space partitioning by stony corals soft corals and benthic algae on the coral reefs of the northern Gulf of Eilat (Red Sea)
}

\author{
Y. BeNAyahu \& Y. Loya \\ Department of Zoology, The George S. Wise Center for Life Sciences, \\ Tel Aviv University; Tel Aviv, Israel
}

\begin{abstract}
The major faunistic and floristic components occupying space on the coral reefs of the northern Gulf of Eilat (Red Sea) are stony corals, soft corals and benthic algae. The percent living coverage of the three components and the relative abundance of the different species of each component were studied by line transects, on the reef flats and the upper forereef zones of nine localities. A wider and higher range of living coverage values of stony corals were recorded at the upper fore-reef zones (18.30-49.09\%) compared with the reef flats $(5.50-31.66 \%)$ at the different stations. The most abundant stony corals on the reef flats are Cyphastrea microphthalma, Stylophora pistillata, Favia favus, Porites lutea, Platygyra lamellina and the hydrozoan Millepora dichotoma. The fire coral $M$. dichotoma dominates the upper fore-reef zone in most of the stations. The average percent living coverage of soft corals on the reef flats ranged between 0.20 and $17.06 \%$, and on the upper fore-reef zones between 1.68 and $15.13 \%$. Seventy percent of the total living coverage of the soft coral community is contributed by 2 to 3 species. They tend to form large monospecific "carpets", such as those composed of Sinularia sp., Sarcopbyton glaucum and Lobophytum pauciflorum. The common benthic algae on the coral reef studied occur as turfs or macroscopic noncalcareous algae. They play a significant role in occupying space, especially on the reef flats. The most abundant algae recorded in all localities are the turfs Sphacelaria tribuloides, Jania sp. and the macroscopic non-calcareous algae Turbinaria elatensis and Colpomenia sinuosa. Comparison between reef flats and upper fore-reef zones, in terms of average living cover of stony corals, shows that the variation among the reef flats is greater than the variation among the upper fore-reef zones. However, there is no significant variation in the average living coverage of soft corals between these two zones. Annual living-coverage values of algae on the reef flats are significantly higher than those of the upper fore-reef zones. Extremely low tides occurring periodically but unpredictably at Eilat cause mass mortality of the benthic communities on the reef flats reopening new spaces for settlement. The coexistence of stony corals, soft corals and algae on the reef ecosystem is due to different biological properties of each component. Opportunistic life histories of certain stony corals and most algae enable quick colonization of newly opened spaces. Lack of predators, high tolerance against abiotic factors and ability to form large aggregates of colonies are suggested as possible factors supporting the existence of soft corals in shallow water. Biological factors such as competition, predation and grazing pressure play an increasingly important role in controlling space utilization by the components studied with the advancement of succession.
\end{abstract}




\section{INTRODUCTION}

This work is concerned with quantitative and qualitative characteristics of the major faunistic and floristic components, which constitute the living coverage on the coral reefs of the northern Gulf of Eilat (Red Sea). The main components are stony corals, soft corals and benthic algae (Fig. 1). Quantitative characteristics studied were percent living coverage and relative abundance of the different species. A comparison is made between the reef flats and upper fore-reef zones, in every locality studied, in connection with space partitioning of the reef by the stony corals, soft corals and algae.

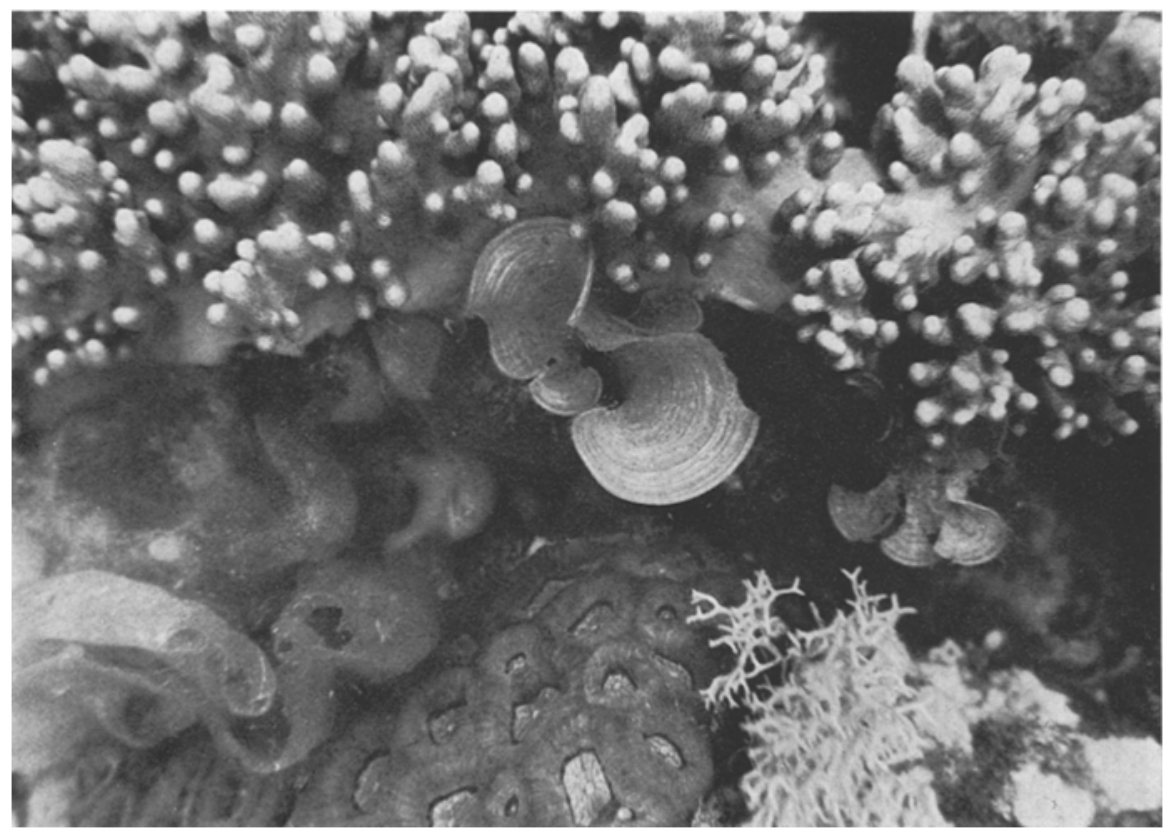

Fig. 1: Dense living coverage of stony corals, soft corals and algae on the reef flat at Eilat. Top: soft coral Sinularia sp.; center: alga Padina sp.; bottom left: alga Colpomenia sinuosa; bottom right: alga Liagora sp.; bottom center: scleractinian coral Favia favus

The community structure of hermatypic corals at the Nature Reserve of Eilat was studied by Loya (1972). Possible effects of pollution and extreme low tides on coral reef communities were examined by Fishelson (1973a, b) and Loya $(1975,1976)$. Quantitative features of communities of stony corals were studied during the last few years by Loya (1972, 1976), Maragos (1972, 1974a, b), Porter (1972a, 1974), Laxton \& Stablum (1974) and Ott (1975).

The soft corals (Octocorallia) consist of five orders: Stolonifera, Gorgonacea, Alcyonacea, Teletacea and Pennatulacea. Quantitative studies of community structure of soft corals are almost lacking. Most of the studies concerning soft corals are mainly taxonomic or descriptive. The present work is concerned only with the orders Stolo- 
nifera and Alcyonacea, and provides for the first time quantitative information on their living coverage, abundance and distribution, in the northern Gulf of Eilat.

Based on the pioneering descriptions of soft corals from the Red Sea (Klunzinger, 1877; Kükenthal, 1913) intensive taxonomic studies were done by Verseveldt (1965, 1969, 1970a, b, 1971, 1974) and Verseveldt \& Cohen (1971). These works provided the opportunity to initiate biological and ecological studies of alcyonarian corals in the Gulf of Eilat (Fishelson, 1970, 1973b; Mergner \& Schuhmacher, 1974; Schuhmacher, 1974, 1975). Other ecological studies dealing with Alcyonacea are scarce and usually constitute a minor part in general descriptions of coral- reef surveys (Faure, 1974; Maragos, 1974b; Nishira \& Yamazato, 1974; Veron et al., 1974). Some works describe quantitative aspects of gorgonian communities (Goldberg, 1973; Kinzie, 1973; Opresko, 1973; Preston \& Preston, 1975; van den Hoek et al., 1975).

Algae in a coral reef ecosystem can be divided into three major categories: Benthic epilithic algae, endolithic algae, and symbiotic algae (within animal tissues). Many studies have been concerned with the symbiotic algae and especially in their role in calcification of corals (see review by Muscatine, 1974). Other works deal with endolithic algae and their possible functions (Odum \& Odum, 1955). The Crustose coralline algae have been studied in connection with their cementing capability and their role in preventing reef erosion (Littler, 1973; Doty, 1974; Vine, 1974; Littler \& Doty, 1975). Benthic algae play a crucial role in a coral-reef maintenance: They assimilate energy consumed by herbivores (Odum \& Odum, 1955; Bakus, 1972); they also play a crucial role in the carbon, oxygen, nitrogen and phosphate cycles (Kinsey \& Domm, 1974).

Algae vegetation is concerned with a wide range of biological and ecological problems (Dahl, 1972; Dart, 1972; Maragos, 1972; Fishelson, 1973a; Randall, 1973; Sammarco et al., 1973; and many others). However, quantitative studies of community structure of algae on coral reefs still remain very poor (Dahl, 1974). In the present work, we have studied the relative contribution to the living coverage of turf and macroscopic non-calcareous algae, stony corals and soft corals of the reef flats and upper fore-reef zones.

Integration of the data concerning the three major faunistic and floristic components of the reef might provide a better understanding of the mechanisms governing their space partitioning in the coral reefs of the northern Gulf of Eilat.

\section{STUDY AREA AND METHODS}

The present study was carried out in nine localities along the western coast of the Gulf of Eilat, ranging from the Nature Reserve of Eilat to Ras el Burqa', approximately $50 \mathrm{~km}$ south of Eilat (Fig. 2). The criteria for choosing the stations were the presence of a well developed and continuous reef flat. The reefs of Eilat are of the fringing type with scleractinian corals as the most important organisms (Loya \& Slobodkin, 1971). All the localities except the reef across the Marine Laboratory of Eilat have a typical structure of shallow lagoon, a well developed reef flat and a steep upper fore-reef zone. The reef across the Marine Laboratory lacks the typical structure 
of a lagoon and a steep upper fore-reef and is characterized by a shallow and wide rocky plate covered by stony corals. The studied reef at Taba is at the southern edge of Wadi Taba. The three stations at Muqebla' are in front of Wadi Muqebla'. The reef flats at Km 202 and $\mathrm{Km} 207$ are across the distance-marking on the highway to Sharm esh Sheikh (Fig. 2).

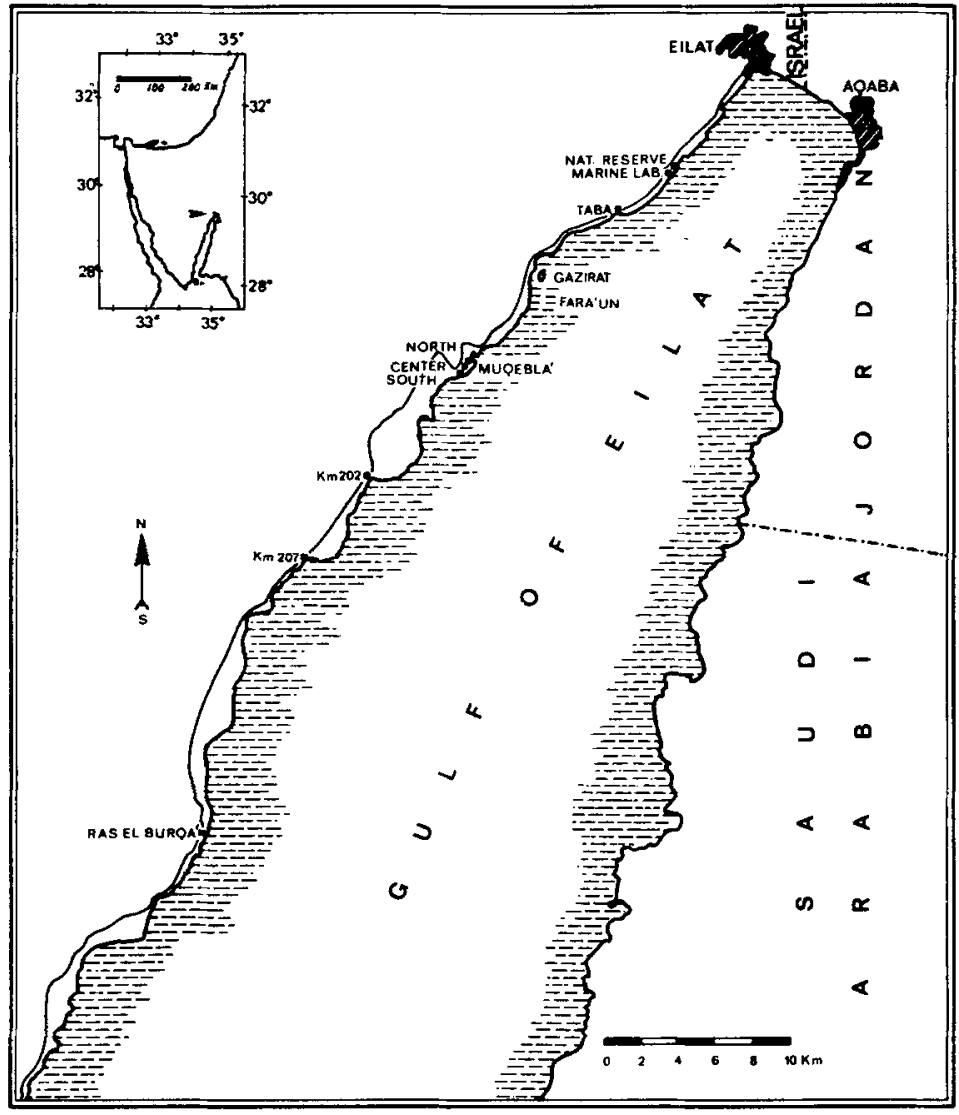

Fig. 2: Index map of northern Gulf of Eilat showing study locations

The sampling method adopted in the present study was line transects, a technique developed by Loya \& Slobodkin (1971) to study community structure of stony corals. This technique was also used for the study of the community structure of soft corals and algae. The line transects were run underwater at the different stations in two reef zones: The reef flats and the upper fore-reef zones (Loya, 1972). Each transect was $10 \mathrm{~m}$ long. The transects were run parallel to the shore and parallel to each other at a fixed interval of $1.0 \mathrm{~m}$ on the reef flat and at intervals of $1.0 \mathrm{~m}$ depth on the upper fore-reef slope. In the wide reef flat of Ras el Burqa' the distance between adjacent transects was 2.0 to $3.0 \mathrm{~m}$, and at the upper fore-reef zone $0.5 \mathrm{~m}$. Table 1 shows the number of transects surveyed at each locality in both reef zones. 
Table 1

Number of transects surveyed at different localities on reef flats and on upper fore-reef zones

\begin{tabular}{|lcc|}
\hline Locality & Reef flat & Upper fore-reef \\
\hline Nature Reserve & $9+6^{*}$ & $3+3$ \\
Marine Laboratory & $8+7$ & 3 \\
Taba & $5+5$ & $4+3$ \\
North Muqebla' & 14 & 3 \\
Center Muqebla' & $6+8$ & 4 \\
South Muqebla' & 11 & $3+3$ \\
Km 202 & 10 & $3+3$ \\
Km 207 & 9 & 17 \\
Ras el Burqa' & $27+29$ & \\
$*$ The ( + ) sign indicates that two parallel series of transects were surveyed in the same \\
zone.
\end{tabular}

In this study, as in the previous one (Loya \& Slobodkin, 1971), an individual of a stony coral was defined as any colony growing independently of its neighbors (i.e. whenever an empty space was recorded between two adjacent colonies). All stony corals and soft corals under the line were recorded and their projected length which intercepted the line was measured to the nearest centimeter. The hydrozoans Millepora dichotoma and $M$. platypbylla were also included in this study, since they are important frame builders of the reef flat at Eilat (Loya, 1972). Whenever confronted with the slightest doubt concerning the species of a certain stony coral or soft coral, a small piece was chopped off and placed into a plastic bag carrying a numbered tag for purposes of exact identification in the laboratory.

The exact locations of the transects at the different stations were carefully marked by knots of red plastic ribbon. This enabled repeated surveys along the same transects in order to detect seasonal changes in living coverage of the turf and macroscopic non-calcareous algae. The living coverage of algae on the reef flat was measured every month and that of the upper fore-reef zones every 2 to 3 months. The measurements were done from March 1974 to February 1975. The algal coverage was recorded along the transects as percent coverage per meter. Although this method provides only an approximation of the living coverage, it is very quick and efficient in obtaining detailed information. Since the algal community is mostly composed of individuals smaller than $2 \mathrm{~cm}$ in length, it was necessary to take samples to the laboratory for further identification of the species.

\section{RESULTS}

\section{Stony corals}

Table 2 summarizes the mean living coverage per transect of stony corals on the reef flats and upper fore-reef zones in the different localities. The lowest living coverage among the reef flats was recorded at Ras el Burqa', the Nature Reserve and South 
Table 2

Average percent cover ( \pm S.D.) of stony corals per transect of $10 \mathrm{~m}$ at the different localities on reef flats and upper fore-reef zones

\begin{tabular}{|lrc|}
\hline \multicolumn{1}{c}{ Locality } & $\begin{array}{c}\text { Average percent cover of stony corals per transect } \\
\text { Reef flat }\end{array}$ & $\begin{array}{c}\text { Upper fore-reef } \\
\text { Und }\end{array}$ \\
\hline Nature Reserve & $6.17 \pm 3.14$ & $24.36 \pm 10.84$ \\
Marine Laboratory & $27.69 \pm 6.14$ & $34.70 \pm 2.10$ \\
Taba & $29.90 \pm 12.10$ & $20.24 \pm 9.55$ \\
North Muqebla' & $17.99 \pm 6.79$ & $24.80 \pm 3.80$ \\
Center Muqebla, & $27.90 \pm 10.50$ & $18.30 \pm 9.12$ \\
South Muqebla' & $7.01 \pm 2.51$ & $40.85 \pm 15.74$ \\
Km 202 & $19.60 \pm 10.15$ & $33.25 \pm 17.96$ \\
Km 207 & $31.66 \pm 17.03$ & $49.09 \pm 16.53$ \\
Ras el Burqa' & $5.50 \pm 5.34$ & \\
\hline
\end{tabular}

Muqebla'. The highest living coverage was recorded at Km 207, Taba, Center Muqebla' and Marine Laboratory stations. The lowest values of living coverage on the upper fore-reef zone were recorded at South Muqubla' and North Muquebla', while the highest values were recorded at Ras el Burqa' and $\mathrm{Km}$ 202. Note the wider and higher range of living coverage values at the upper fore-reef zone (18.3-49.09\%) compared with the reef flats $(5.50-31.66 \%)$.

The hermatypic coral species composition on the reef flats and upper fore-reef zones is given in Tables 3 and 4 respectively, represented in code numbers (see Table 9). The species are ranked according to their relative contribution to living coverage within the transects. Loya (1972) has shown that a high correlation exists between relative contribution to living coverage of hermatypic corals and their relative abundance at the reefs of Eilat. The same result was obtained in the present study and, therefore, in the following discussion we equate high abundance to high contribution to living coverage. It should be noted that there is some variation in the ranking order of the most abundant species in the different localities. However, 5 to 6 coral species are dominant in most of the stations: Cyphastrea micropbthalma, Stylophora pistillata, Favia favus, Porites lutea, Platygyra lamellina, and the hydrozoan Millepora dichotoma. Some species are very abundant only in a few stations and sometimes only in one locality such as Leptastrea transversa, Acanthastrea echinata, Goniastrea retiformis and Pavona decussata. It is interesting to note the relative rareness of Millepora dicbotoma at the reef flat of Ras el Burqa', where this species is far from being ranked among the ten most abundant species (Table 3).

On the other hand some species such as Acropora humilis, A. scandens and Montipora tuberculosa are very common on the reef flat of Ras el Burqa', while the same species are quite rare or completely absent in other localities. Table 4 clearly demonstrates the domination of Millepora dichotoma on the upper fore-reef slopes forming the Millepora zone (Loya, 1972). In contrast to the reef flats, it is more difficult to point out the most abundant coral species on the upper fore-reef slopes. However, besides $M$. dichotoma the corals Cyphastrea micropbthalma, Favia favus, Porites lutea, Pavona decussata, Platygyra lamellina, Stylophora pistillata etc. are ranked in the 
Table 3

Species rank of stony corals on the reef flats at nine localities along the northern Gulf of Eilat, based on their relative contribution to living coverage. Coral species are represented as code numbers (see Table 9)

\begin{tabular}{|c|c|c|c|c|c|c|c|c|c|}
\hline 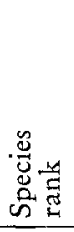 & 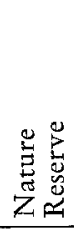 & 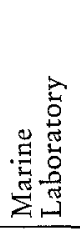 & $\frac{\sqrt{0}}{\text { ली }}$ & 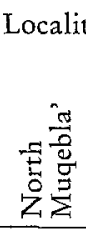 & 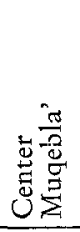 & 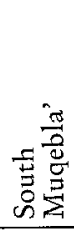 & 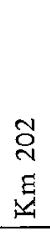 & 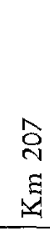 & 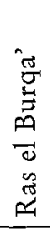 \\
\hline 1 & 98 & 98 & 98 & 60 & 60 & 60 & 81 & 81 & 60 \\
\hline 2 & 60 & 2 & 81 & 81 & 81 & 98 & 98 & 31 & 25 \\
\hline 3 & 81 & 60 & 70 & 2 & 98 & 2 & 2 & 98 & 2 \\
\hline 4 & 53 & 81 & 79 & 53 & 2 & 87 & 60 & 60 & 70 \\
\hline 5 & 87 & 70 & 66 & 67 & 87 & 53 & 70 & 68 & 29 \\
\hline 6 & 2 & 9 & 60 & 70 & 77 & 57 & 31 & 2 & 16 \\
\hline 7 & 70 & 80 & 53 & 79 & 53 & 81 & 79 & 70 & 67 \\
\hline 8 & 42 & 67 & 68 & 87 & 70 & 70 & 87 & 42 & 53 \\
\hline 9 & 79 & 41 & 42 & 98 & 83 & 42 & 99 & 99 & 83 \\
\hline 10 & 23 & 53 & 3 & 80 & 66 & 83 & 66 & 69 & 81. \\
\hline 11 & 77 & 79 & 59 & 9 & 65 & 79 & 9 & 53 & 9 \\
\hline 12 & 83 & 65 & 2 & 66 & 68 & 31 & 24 & 83 & 75 \\
\hline 13 & 78 & 87 & 69 & 64 & 14 & 67 & 68 & 79 & 87 \\
\hline 14 & 9 & 66 & 65 & 68 & 9 & 23 & 53 & 87 & 79 \\
\hline 15 & 24 & 64 & 99 & 69 & 8 & 55 & 57 & 86 & 15 \\
\hline 16 & 66 & 23 & 87 & 78 & 42 & 80 & 69 & 75 & 89 \\
\hline 17 & 65 & 82 & 24 & 11 & 75 & 9 & 78 & 24 & 26 \\
\hline 18 & 30 & 42 & 6 & 75 & 16 & 6 & 23 & 44 & 65 \\
\hline 19 & 26 & 29 & 83 & 41 & 80 & 64 & 67 & 16 & 10 \\
\hline 20 & 67 & 15 & 44 & 29 & 6 & - & 42 & 82 & 6 \\
\hline 21 & 31 & 90 & 67 & 31 & 67 & - & 65 & 20 & 31 \\
\hline 22 & 75 & 69 & 21 & 83 & 62 & - & 80 & 67 & 66 \\
\hline 23 & 57 & 68 & 86 & 65 & 1 & - & 94 & 64 & 24 \\
\hline 24 & 41 & 6 & 41 & 23 & 78 & - & 75 & 32 & 78 \\
\hline 25 & 62 & - & 57 & 89 & 31 & - & 11 & 65 & 30 \\
\hline 26 & 69 & - & 8 & 40 & 69 & - & 86 & 66 & 68 \\
\hline 27 & 89 & - & 89 & 15 & 79 & - & 3 & 29 & 98 \\
\hline 28 & 8 & - & 40 & 16 & 64 & - & 83 & 27 & 23 \\
\hline 29 & 86 & - & 1 & 90 & 58 & - & - & 9 & 17 \\
\hline 30 & 6 & - & 75 & - & 57 & - & - & 80 & 42 \\
\hline 31 & - & - & 85 & - & 5 & - & - & 97 & 69 \\
\hline 32 & - & - & 82 & - & 11 & - & - & - & 7 \\
\hline 33 & - & - & 32 & - & 94 & - & - & - & 73 \\
\hline 34 & - & - & 29 & - & 90 & - & - & - & 18 \\
\hline 35 & - & - & 9 & - & 20 & - & - & - & 3 \\
\hline 36 & - & - & 11 & - & 89 & - & - & - & 21 \\
\hline 37 & - & - & - & - & 23 & - & - & - & - \\
\hline 38 & - & - & - & - & 86 & - & - & - & - \\
\hline
\end{tabular}

ten most abundant species. Certain species create local aggregations and are very abundant only in one or two stations, such as Tubastrea micrantha in South Muqebla', Favia stelligera in $\mathrm{Km} 207$ and Seriatopora caliendrum in South and Center Muqebla'. Ras el Burqa' is interesting among the studied reefs since it exhibits the lowest living coverage on the reef flat and the highest living coverage on the upper fore-reef slope (Table 2). It has the widest reef flat (approximately $70 \mathrm{~m}$ compared with $10-15 \mathrm{~m}$ 
Table 4

Species rank of stony corals on the upper fore-reef zones at eight localities along the Gulf of Eilat, based on their relative contribution to living coverage. Coral species are represented as code numbers (see Table 9)

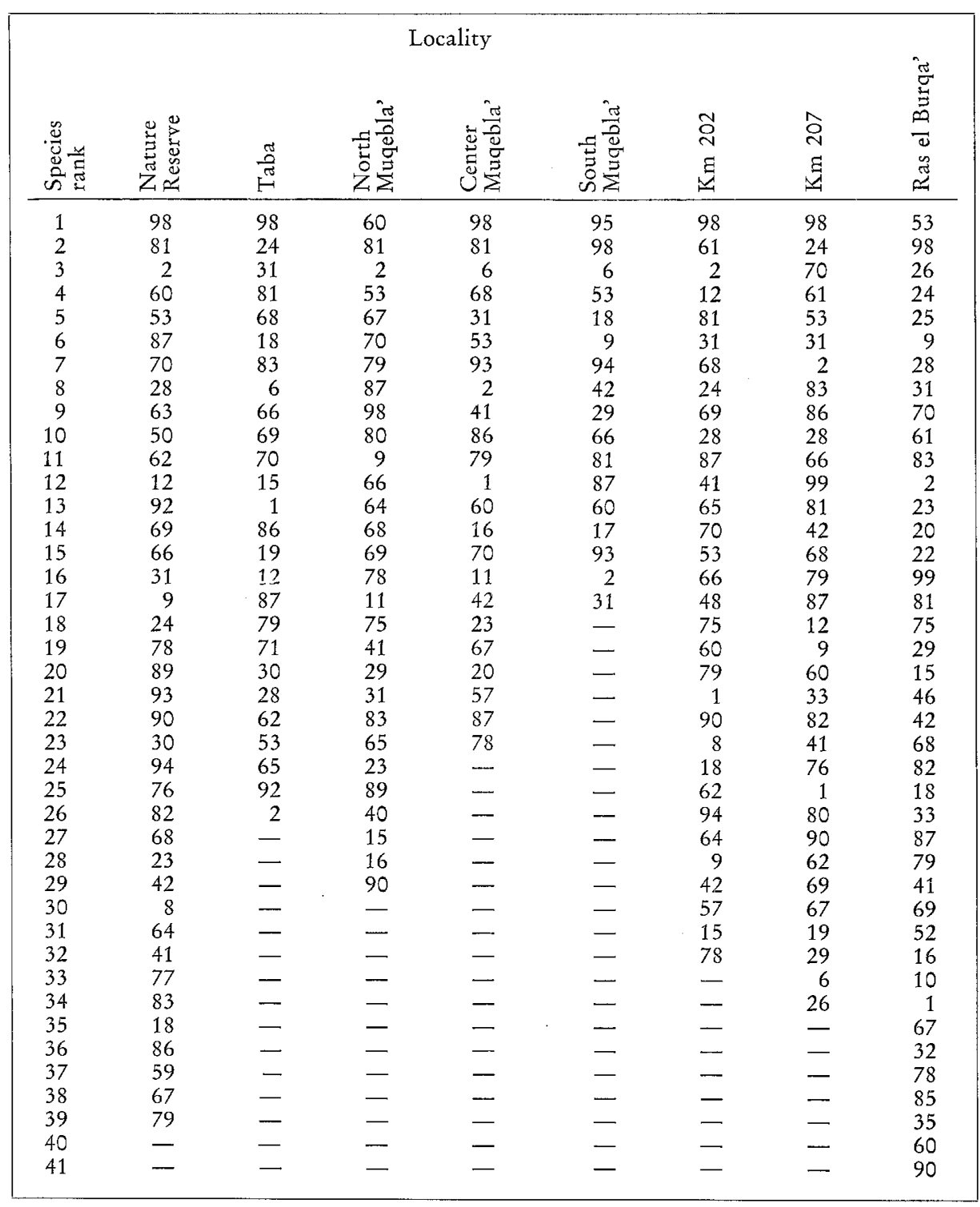

of other localities) and the largest upper fore-reef ( $8 \mathrm{~m}$ compared with $4 \mathrm{~m}$ in most of the other localities). It is also unique among the studied reefs in a different species composition both on the reef flat and upper fore-reef zones (Tables 3 and 4). Thus, the 
coral Porites lutea is the most abundant species on the upper fore-reef, creating huge clumps, while in all other stations it is much less abundant. Other abundant coral species in this zone, which do not appear in the rest of the stations, are Acropora hemprichi, A. byacintbus, $A$. humilis and $A$. eurystoma.

\section{Sof torals}

Table 5 presents the mean living coverage of soft corals in the different localities. The average percent cover per transect on the reef flats and upper fore-reef zones seems to be quite similar, with some exceptions: the low living coverage across the Marine Laboratory $(0.2 \%)$ and the relatively high coverage on the reef flat of $\mathrm{Km} 202$ $(17.06 \%)$ and the upper fore-reef of South Muqebla' $(15.13 \%)$.

\section{Table 5}

Average percent cover ( \pm S.D.) of soft corals per $10-\mathrm{m}$ transect at different localities on reef flats and upper fore-reef zones

\begin{tabular}{|c|c|c|}
\hline \multirow{2}{*}{ Locality } & \multicolumn{2}{|c|}{ Mean percent cover of soft corals per $10 \mathrm{~m}$} \\
\hline & Reef flat & Upper fore-reef \\
\hline Nature Reserve & $3.27 \pm 2.86$ & $3.98 \pm 2.84$ \\
\hline Marine Laboratory & $0.20 \pm 0.22$ & - \\
\hline Taba & $2.84 \pm 2.04$ & $4.57 \pm 0.77$ \\
\hline North Muqebla' & $4.87 \pm 4.05$ & $1.68 \pm 1.13$ \\
\hline Center Muqebla' & $3.65 \pm 2.84$ & $8.65 \pm 3.79$ \\
\hline South Muqebla" & $4.33 \pm 3.46$ & $15.13 \pm 6.93$ \\
\hline $\mathrm{Km} 202$ & $17.06 \pm 15.00$ & $6.04 \pm 3.84$ \\
\hline $\mathrm{Km} 207$ & $7.07 \pm 7.77$ & $4.47 \pm 2.73$ \\
\hline Ras el Burqa' & $4.22 \pm 4.00$ & $10.13 \pm 10.75$ \\
\hline
\end{tabular}

In the present study, 16 species of octocorals representing the orders Alcyonacea and Stolonifera were collected. Tables 6 and 7 provide the ranking order of soft corals according to their contribution to the living coverage of the octocoral communities on the reef flats and upper fore-reef zones, respectively. It should be noted that $70 \%$ of the total living coverage of soft corals is contributed by 2 to 3 species (Tables 6 and 7, Figs. 3 and 4). This result may be best demonstrated from the reef flats of Km 202 and South Muqebla', where the first two most abundant species constitute 80 to $90 \%$ of the total living coverage of the octocoral community (Table 6). At $\mathrm{Km}$ 202, for example, Sinularia compressa alone contributes more than $80 \%$ to the total living coverage of the octocoral community on the reef flat. A typical characteristic of soft corals is their tendency to form large monospecific "carpets" such as those of Sinularia sp., Sarcophyton glaucum (Fig. 4) and Lobopbytum pauciflorum. Such a carpet may reach sometimes an area of several quadrate meters. Some other octocoral species e.g. Clavularia hamra, Tubipora musica, Paralemnalia thyrsoides, and Stereonephthya cundabiluensis, have never been seen to cover large areas and are usually sporadic to rare in their abundance. 


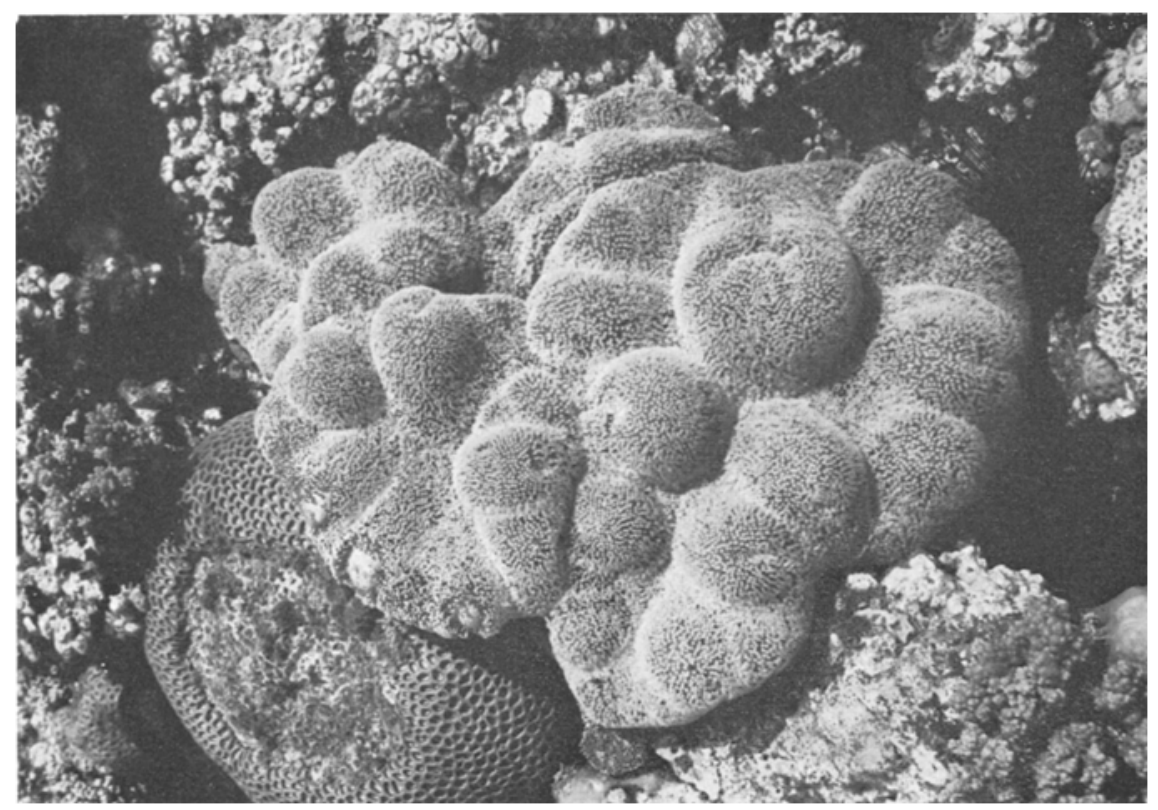

Fig. 3: The soft coral Sarcopbyton glaucum overgrows a colony of the stony coral Favites sp.

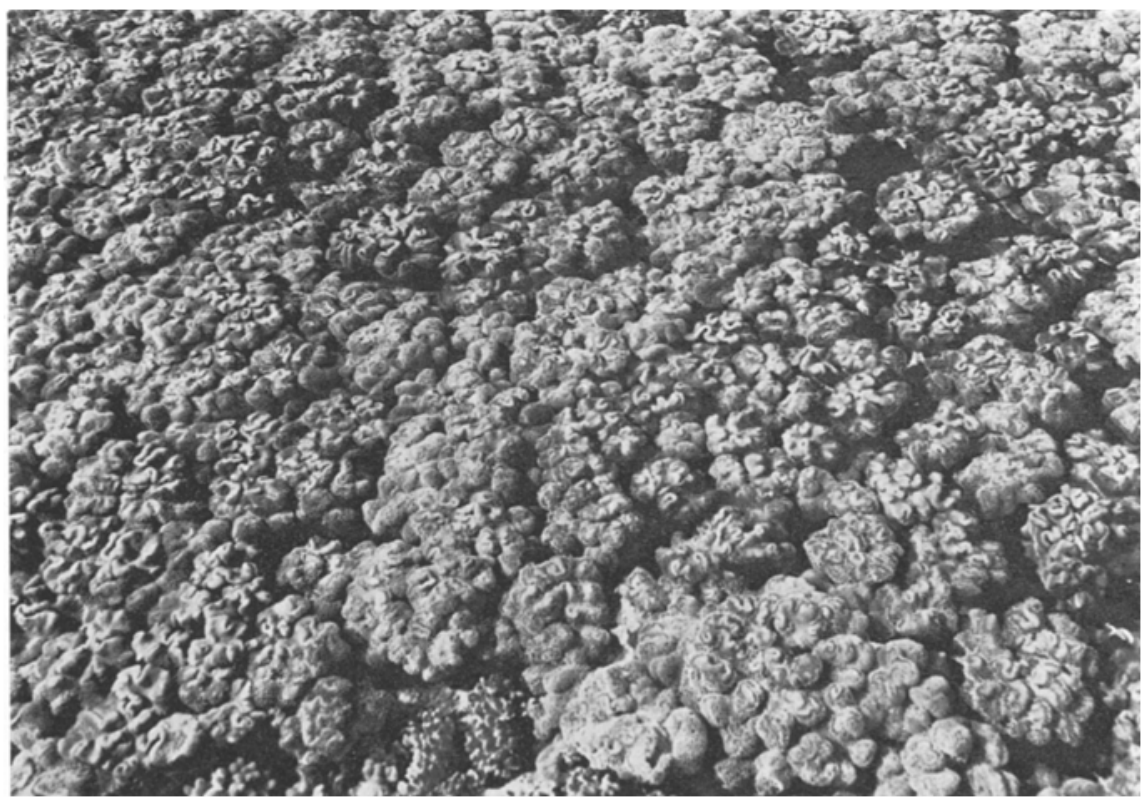

Fig. 4: Space monopolization of the reef flat by a monospecific "carpet" of Sarcopbyton sp. which covers the reef flat across $\mathrm{Km} 207$ on the way to Sharm esh Sheikh 
Table 6

Species rank of soft corals expressed as relative percent cover on reef flats

\begin{tabular}{|c|c|c|c|}
\hline Locality & Rank & Species & Cover $(\%)$ \\
\hline \multirow{6}{*}{ Nature reserve } & 1 & Litophyton arboreum & 36.0 \\
\hline & 2 & Sinularia leptoclados & 33.3 \\
\hline & 3 & Sinularia compressa & 26.2 \\
\hline & 4 & Parerythropodium fulvum fulvum & 3.1 \\
\hline & 5 & Tubipora musica & 0.7 \\
\hline & 6 & Clavularia bamra & 0.7 \\
\hline \multirow{6}{*}{ Taba } & 1 & Parerythropodium fulvum fulvum & 44.0 \\
\hline & 2 & Sinularia leptoclados & 20.8 \\
\hline & 3 & Sinularia compressa & 16.2 \\
\hline & 4 & Litophyton arboreum & 11.6 \\
\hline & 5 & Heteroxenia fuscescens & 6.7 \\
\hline & 6 & Tubipora musica & 0.7 \\
\hline \multirow{7}{*}{ North Muqebla' } & 1 & Sinularia leptoclados & 23.9 \\
\hline & 2 & Lobophytum pauciflorum & 23.4 \\
\hline & 3 & Sinularia grayi & 21.8 \\
\hline & 4 & Litophyton arboreum & 19.3 \\
\hline & 5 & Parerythropodium fulvum fulvum & 6.4 \\
\hline & 6 & Sinularia compressa & 4.1 \\
\hline & 7 & Heteroxenia fuscescens & 1.1 \\
\hline \multirow{9}{*}{ Center Muqebla' } & 1 & Sinularia leptoclados & 46.4 \\
\hline & 2 & Parerytbropodium fulvum fulvum & 23.5 \\
\hline & 3 & Xenia sp. & 16.1 \\
\hline & 4 & Cladiella pachyclados & 4.6 \\
\hline & 5 & Lithopbyton arboreum & 2.9 \\
\hline & 6 & Tubipora musica & 2.9 \\
\hline & 7 & Sarcopbyton glaucum & 2.1 \\
\hline & 8 & Clavularia bamra & 1.1 \\
\hline & 9 & Heteroxenia fuscescens & 0.4 \\
\hline \multirow{9}{*}{ South Muqebla' } & 1 & Parerytbropodium fulvum fuloum & 42.7 \\
\hline & 2 & Sinularia leptoclados & 37.9 \\
\hline & 3 & Lobophytum pauciflorum & 8.3 \\
\hline & 4 & Xenia sp. & 3.5 \\
\hline & 5 & Litophyton arboreum & 2.3 \\
\hline & 6 & Sinularia grayi & 1.8 \\
\hline & 7 & Tubipora musica & 1.8 \\
\hline & 8 & Heteroxenia fuscescens & 1.2 \\
\hline & 9 & Clawularia bamra & 0.5 \\
\hline \multirow{7}{*}{$\mathrm{Km} 202$} & 1 & Sinularia compressa & 80.8 \\
\hline & 2 & Sinularia leptoclados & 11.6 \\
\hline & 3 & Sarcopbyton glaucum & 5.3 \\
\hline & 4 & Parerythropodium fulvum fulvum & 1.1 \\
\hline & 5 & Cladiella pacbyclados & 0.6 \\
\hline & 6 & Heteroxenia fuscescens & 0.4 \\
\hline & 7 & Tubipora musica & 0.2 \\
\hline \multirow{5}{*}{$\mathrm{Km} 207$} & 1 & Litopbyton arboreum & 50.7 \\
\hline & 2 & Sinularia leptoclados & 26.1 \\
\hline & 3 & Cladiella pachyclados & 11.3 \\
\hline & 4 & Parerytbropodium fulvum fulvum & 7.5 \\
\hline & 5 & Heteroxenia fuscescens & 3.5 \\
\hline \multirow{11}{*}{ Ras el Burqa' } & 6 & Sarcopbyton glaucum & 0.9 \\
\hline & 1 & Sinularia compressa & 42.8 \\
\hline & 2 & Sinularia leptoclados & 16.6 \\
\hline & 3 & Litopbyton arborevm & 13.6 \\
\hline & 4 & Parerythropodium fulvum fulvum & 6.9 \\
\hline & 5 & Cladiella pacbyclados & 4.9 \\
\hline & 6 & Sinularia polydactyla & 4.7 \\
\hline & 7 & Lobopbytum pauciflorum & 4.7 \\
\hline & 8 & Sarcophyton glaucum & 3.7 \\
\hline & 9 & Tubipora musica & 1.7 \\
\hline & 10 & Stereonepbthya cundabiluensis & 0.4 \\
\hline
\end{tabular}


Table 7

Species rank of soft corals expressed as relative percent cover at upper fore-reef zones

\begin{tabular}{|c|c|c|c|}
\hline Locality & Rank & Species & Cover $(\% / 0)$ \\
\hline Nature reserve & $\begin{array}{l}1 \\
2 \\
3\end{array}$ & $\begin{array}{l}\text { Sinularia leptoclados } \\
\text { Parerytbropodium fulvum fulvum } \\
\text { Stereonepbtbya cundabiluensis }\end{array}$ & $\begin{array}{r}70.3 \\
22.6 \\
7.1\end{array}$ \\
\hline Taba & $\begin{array}{l}1 \\
2\end{array}$ & $\begin{array}{l}\text { Sinularia leptoclados } \\
\text { Clavulria bamra }\end{array}$ & $\begin{array}{l}83.2 \\
16.8\end{array}$ \\
\hline North Muqebla' & $\begin{array}{l}1 \\
2 \\
3 \\
4\end{array}$ & $\begin{array}{l}\text { Parerythropodium fuloum fulvum } \\
\text { Sinularia leptoclados } \\
\text { Sarcopbyton glaucum } \\
\text { Heteroxenia fuscescens }\end{array}$ & $\begin{array}{r}52.4 \\
27.4 \\
11.9 \\
8.3\end{array}$ \\
\hline Center Muqebla' & $\begin{array}{l}1 \\
2 \\
3 \\
4 \\
5\end{array}$ & $\begin{array}{l}\text { Sinularia leptoclados } \\
\text { Parerythropodium fulvum fulvum } \\
\text { Heteroxenia fuscescens } \\
\text { Sinularia mayi } \\
\text { Litopbyton arboreum }\end{array}$ & $\begin{array}{r}36.2 \\
30.1 \\
22.8 \\
10.7 \\
0.2\end{array}$ \\
\hline South Muqebla' & $\begin{array}{l}1 \\
2 \\
3 \\
4 \\
5\end{array}$ & $\begin{array}{l}\text { Xenia sp. } \\
\text { Parerytbropodium fulvum fulvum } \\
\text { Heteroxenia fuscescens } \\
\text { Litopbyton arboreum } \\
\text { Sinularia leptoclados }\end{array}$ & $\begin{array}{r}50.4 \\
45.6 \\
2.2 \\
0.9 \\
0.9\end{array}$ \\
\hline $\mathrm{Km} 202$ & $\begin{array}{l}1 \\
2 \\
3 \\
4 \\
5 \\
6\end{array}$ & $\begin{array}{l}\text { Sinularia leptoclados } \\
\text { Sarcopbyton glaucum } \\
\text { Litopbyton arboreum } \\
\text { Parerytbropodium fulvum fulvum } \\
\text { Paralemnalia thyrsoides } \\
\text { Heteroxenia fuscescens }\end{array}$ & $\begin{array}{r}39.1 \\
33.2 \\
16.9 \\
9.6 \\
0.6 \\
0.6\end{array}$ \\
\hline $\mathrm{Km} 207$ & $\begin{array}{l}1 \\
2 \\
3 \\
4 \\
5 \\
6 \\
7\end{array}$ & $\begin{array}{l}\text { Sinularia leptoclados } \\
\text { Litopbyton arboreum } \\
\text { Tubipora musica } \\
\text { Sinularia mayi } \\
\text { Parerytbropodium fulvum fulvum } \\
\text { Sinularia compressa } \\
\text { Heteroxenia fuscescens }\end{array}$ & $\begin{array}{r}46.3 \\
19.4 \\
11.9 \\
9.3 \\
7.1 \\
5.6 \\
0.4\end{array}$ \\
\hline Ras el Burqa' & $\begin{array}{l}1 \\
2 \\
3 \\
4\end{array}$ & $\begin{array}{l}\text { Litophyton arboreum } \\
\text { Sinularia leptoclados } \\
\text { Sinularia mayi } \\
\text { Sarcopbyton glaucum }\end{array}$ & $\begin{array}{r}41.2 \\
39.4 \\
14.7 \\
4.7\end{array}$ \\
\hline
\end{tabular}

\section{A $\lg$ a e}

The common benthic algae on the coral reefs of the Gulf of Eilat occur as turfs or macroscopic non-calcareous algae. They play a highly significant role in occupying potential substrate for settlement, especially in shallow water. In order to determine their role in the coral-reef ecosystem, we have followed the seasonal cycle of these algae during the year (Benayahu \& Loya, in preparation). Based on this pattern, we calculated an index which quantifies the total annual algal-coverage on the reef flats and upper fore-reef zones. This value is calculated as the ratio between the total annual cover of algae $(\mathrm{m})$ measured in a certain zone, and the total length of transects (m) surveyed in this zone. Table 8 shows the calculated values for the reef flats and 
upper fore-reef zones in the different stations. It is apparent from Table 8 that the values for total living coverage of algae on the reef flats are significantly higher than those for the upper fore-reef slopes ( $t$-test, $p<0.05$ ). Note the high variability of living coverage between the different stations. Thus, a wide range of values was recorded on the reef flats $(3.0-75.4 \%)$ and upper fore-reef slopes $(3.4-22.1 \%)$.

One of the purposes of this study was to describe genera composition of algae and, when possible, species composition of the turf community in the different stations. Algal identification is difficult, since most of the species are less than $2 \mathrm{~cm}$ high. Some species have a total length of only a few $\mathrm{mm}$.

In all studied areas one of the most abundant turf algae is Sphacelaria tribuloides. This brown alga may be found growing almost on every solid substrate on the coral reef. It covers dead stony corals of different growth forms (branched, massive or encrusting). $S$. tribuloides may often be encountered as low mats covering dead colonies of octocorals, valves of the giant clam Tridacna or shells of the gastropod Trochus dentatus. This species serves as a substrate for different epiphy tic turf algae.

Table 8

Relative percent cover of algae, calculated as the ratio between total annual cover and total length of transects surveyed during the year at the localities studied

\begin{tabular}{|llccc|}
\hline \multicolumn{1}{|c}{ Locality } & $\begin{array}{l}\text { Reef } \\
\text { zon. }\end{array}$ & $\begin{array}{c}\text { Total length of } \\
\text { transects surveyed } \\
\text { during a year } \\
(\mathrm{m})\end{array}$ & $\begin{array}{c}\text { Annual } \\
\text { cover of algae } \\
(\mathrm{m})\end{array}$ & $\begin{array}{c}\text { Relative } \\
\text { cover of algae } \\
(\% / 0)\end{array}$ \\
\hline Nature Reserve & R.F. & 1010 & 619.20 & 61.30 \\
Marine Laboratory & U.F.R. & 170 & 17.35 & 10.20 \\
Taba & R.F. & 1500 & 45.00 & 3.00 \\
North Muqebla' & R.F. & 1100 & 150.00 & 13.70 \\
& U.F.R. & 150 & 16.73 & 11.15 \\
Center Muqebla' & R.F. & 1520 & 365.22 & 24.02 \\
& U.F.R. & 200 & 15.00 & 7.50 \\
South Muqebia' & R.F. & 1510 & 230.30 & 15.25 \\
& U.F.R. & 150 & 7.16 & 4.80 \\
Km 202 & R.F. & 650 & 222.90 & 34.29 \\
& U.F.R. & 120 & 9.66 & 8.10 \\
Km 207 & R.F. & 1080 & 99.70 & 9.22 \\
& U.F.R. & 210 & 7.19 & 3.40 \\
Ras el Burqa' & R.F. & 950 & 235.24 & 24.70 \\
& U.F.R. & 190 & 30.79 & 16.20 \\
& R.F. & 1740 & 1312.54 & 75.43 \\
\hline
\end{tabular}

The main species and genera that usually appear in the turf community are: among the green algae - Dictyosphaerea cavernosa, Acetabularia sp; the brown algae - Dictyota sp., Cystoseira sp., Padina sp., Colpomenia sinuosa, Hydroclatbrus clathratus, Sargassum sp.; the red algae - Ceramium sp., Pocockiella variegata, Polysiphonia sp., Hypnea sp., Champia sp., Gelidium sp., Jania sp., Laurencia sp., Gracilaria sp., Dasya sp., Peysonellia sp., Chondria sp., Herposiphonia sp. and Liagora sp. 
Table 9

Species code numbers of stony corals. (After Loya, 1972)

\begin{tabular}{|c|c|}
\hline 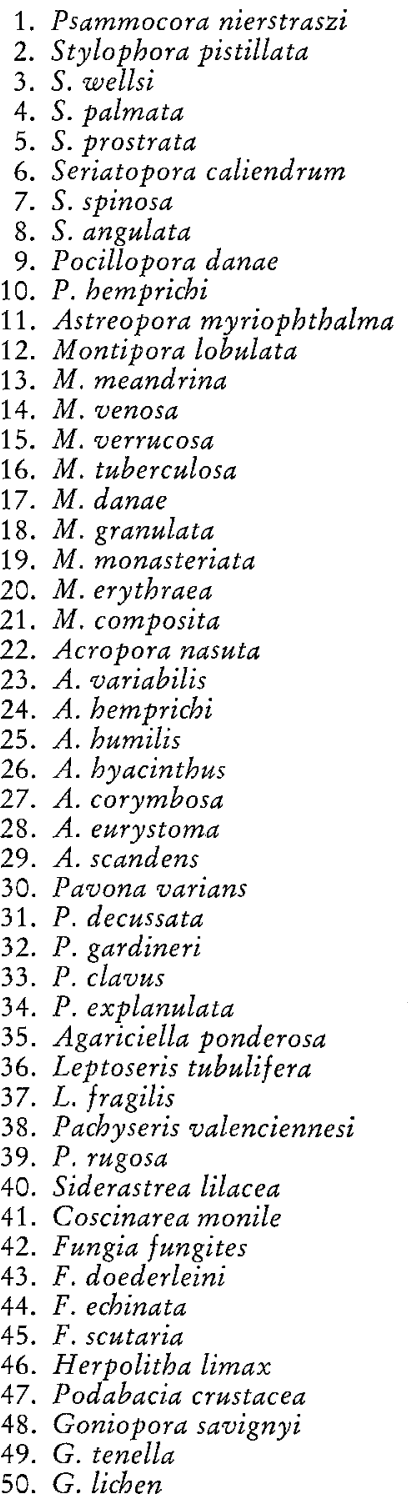 & 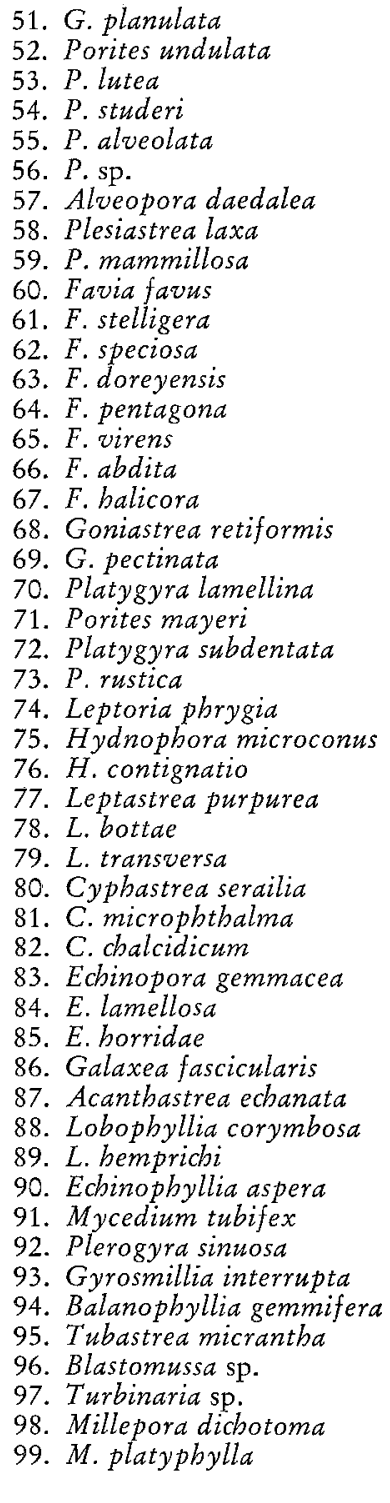 \\
\hline
\end{tabular}

The red alga Pocockiella variegata grows in dense aggregations and usually fills spaces among branches of dead stony corals such as Seriatopora sp., Acropora sp., and Stylophora sp. Some turf algae may appear also in a macroscopic non-calcareous growth form, for example, Padina sp., Dictyota sp., Hydroclatbrus clathratus, Cystoseira sp., 
Sargassum sp., Liagora sp., and Colpomenia sinuosa. The macroscopic non-calcareous brown alga Turbinaria elatensis is one of the most abundant algae that dominate the reef flats of the Gulf of Eilat. The most common turf algae of the upper fore-reef zones are Pocockiella variegata, Peysonellia sp. and Sphacelaria tribuloides.

\section{DISCUSSION}

Space for settlement on a coral reef has been shown to be one of the most important limiting factors in the coral-reef ecosystem (Lang, 1971, 1973). The present study examines space partitioning by stony corals, soft corals and benthic algae, in terms of percentage of living cover on the reef flats and the upper fore-reef zones. The contribution of each component to the total living coverage served as a criterion of comparison, between the nine localities studied, in the northern Gulf of Eilat. Figure 5 illustrates the results of the comparisons between the mean percent coverage of hermatypic corals and octocorals in the studied areas. The significance of differences

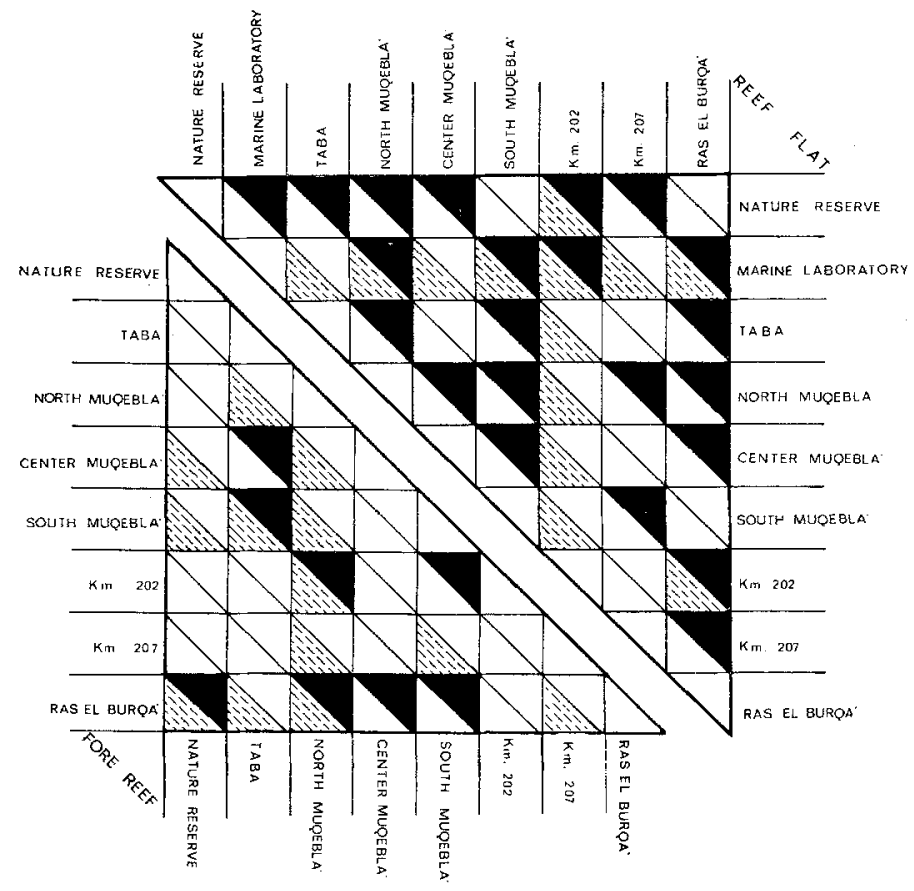

Fig. 5: Statistical comparisons between mean percent living coverage of hermatypic corals and of octocorals. Upper half of figure: reef flats; lower half: upper fore-reef zones. Each square is divided into two small triangles; upper triangle: stony corals; lower: soft corals. Black triangles: significant difference $(\mathrm{P}<0.05)$ in living coverage of stony corals between two stations. Dashed triangels: significant differences $(P<0.05)$ in living coverage of soft corals between two stations. Blank triangles: no significant difference $(\mathbf{P}>0.05)$ 
between the different stations, within the reef flats and upper fore-reef zones were tested by $t$-tests after arcsine transformation. It can be seen that 22 out of 36 comparisons of the mean percent coverage of stony corals on the reef flats indicate significant differences $(P<0.05$ ), while only 8 out of 28 such comparisons within the upper fore-reef zones are significantly different $(P<0.05)$. Hence, a greater variability of the mean coverage of scleractinian corals exists within the reef flats than within the upper fore-reef zones ( $t$-test for equality of percentages, $\mathrm{P}<0.05$ ). Applying the same method of analysis to the average living coverage of octocorals points out, that 13 out of 36 comparisons within the reef flats indicate significant differences, while within the upper fore-reef zones 13 out of 28 comparisons are significantly different $(P<0.05)$. The t-test of equality of percentages shows that no significant difference exists between the mean living cover variability of soft corals in the reef flats versus the upper fore-reef zones $(\mathrm{P}>0.05)$.

The turf algae and macroscopic non-calcareous benthic algae are highly variable in their annual pattern of living coverage (Table 8). The results shown in Table 8 and Figure 5 emphasize the high variability in the pattern of space utilization by stony corals, soft corals and algae in the various localities. The coexistence of the three major components discussed, largely depends on available settlement space, which constitutes a limited resource they may be competing for (Fig. 6). The amount of resource overlap among coexisting species will determine the degree of competition (Sale, 1974). Complete monopolization of space by stony corals, soft corals or algae does not occur in

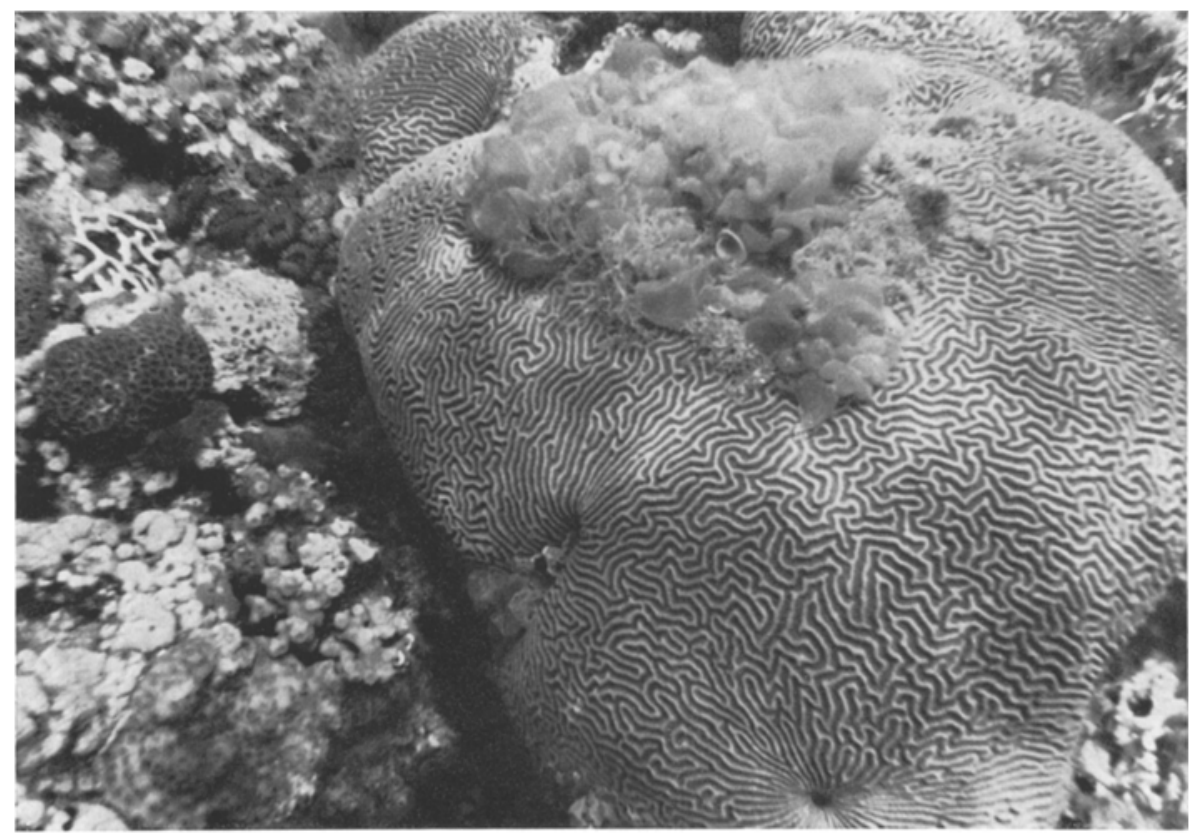

Fig. 6: Space for settlement is a limited resource on a coral reef. Due to low tides, top portions of the brain coral Platygyra lamellina are denuded and subsequently quidkly colonized by the macroscopic non-calcareous algae Colpomenia sinuosa 
either the reef flats or upper fore-reef zones. Even in the reef flats of the Nature Reserve and Ras el Burqa', where living coverage of algae is very high (Table 8), stony corals and soft corals are not excluded. In the upper fore-reef zones living coverage of algae is relatively low (Table 8), and yet stony corals and soft corals do not monopolize the substrate.

Dayton (1971) has demonstrated for a benthic marine habitat, the rocky intertidal zone, that substrate space is potentially the most important limiting resource. Its utilization is controlled by a combination of physical and biological disturbances. Dayton emphasized the crucial task of disturbance factors in preventing a monopolization process in an area.

Fishelson (1973b) and Loya (1976) emphasized the possible ecological role of extreme low tides, which occur periodically but irregularly at the Gulf of Eilat. Such a disturbance could be a factor that prevents crowding on the reef flat and prevents potential dominant competitors from monopolizing the available space. The mass mortality of benthic organisms resulting from the catastrophic low tides reopens new space for settlement of planktonic larvae and spores on the substrate. Thus, space partitioning on shallow water by the three faunistic and floristic components studied may be also attributed to physical factors as extremely low tides. The coexistence of stony corals, soft corals and algae on the coral-reef ecosystem is due to different biological properties of each component. Loya (1976) discussed several traits of scleractinian corals that seem to be advantageous in reef areas that are opened for recolonization after a catastrophe. He suggested that the most opportunistic species among the shallow water corals of Eilat can be expected to breed throughout the year, and are thus most likely to be the first to recolonize occasional denuded areas on the reef. In addition, rapid growth and encrusting growth form of the corals were suggested as advantageous traits in such areas.

The monospecific soft coral carpets, described in the present work, may be the strategy adopted by soft corals such as Sinularia, Sarcopbyton, Parerytbropodium fulvum fulvum etc., in order to rapidly colonize any space reopened for colonization after a catastrophe.

In contrast to the reef flat community, the Millepora zone, situated 0.5 to $2.0 \mathrm{~m}$ below the reef flat, is not exposed to the air during catastrophic low tides. Here, interspecific competition is not interrupted by low tides and has a chance to become complete. Due to domination by $M$. dichotoma, this zone has high hermatypic coral coverage but low diversity (Loya, 1976). It is suggested that lack of predators, high tolerance against abiotic factors, such as extremely low tides and ability to form large aggregates (the typical carpets of Sinularia, Sarcophyton and Lobophytum) are the major possible factors supporting the existence of soft corals in shallow water.

Dayton (1972) claimed that annual species of algae are fugitive species and they are expected to succeed in disturbed areas. Several investigators show that algae are the first to colonize new substrate introduced to a coral reef ecosystem, as well as skeletons of dead stony corals (Randall, 1973; Sammarco et al., 1973; Tsuda \& Kami, 1973; Belk \& Belk, 1975; and others). Preliminary experiments dealing with colonization of benthic organisms on artificial substrates at the coral reef of Eilat indicated that turf algae are covering very rapidly the new available space (Y.B., personal 
observations). It can be concluded that each component has its own features that may lead to utilization of space after catastrophic low tides.

In addition, physical factors, such as wave action, seasonal variations in temperature, salinity and light (see Loya, 1972) may influence the relative success of stony corals, soft corals and algae in space utilization.

The biological factors, as competition and predation, play an increasingly important role with the advancement of succession and the decrease in available space for development and growth of the major components studied. Predation pressure is one of the most important biological disturbances in preventing monopolization of reef areas (Porter, 1972b) and often is the major factor dictating the partitioning of the available space on the reef. The term predation includes eating of animal tissues by carnivores or grazing activity done by herbivores, such as fishes or sea urchins on a coral reef. The great importance of grazing in the coral-reef ecosystem has been discussed by many investigators (Randall, 1961; Dahl, 1972; Sammarco et al., 1973; Tsuda \& Kami, 1973; Schuhmacher, 1974; Ogden, 1976; and others). Grazing activity is one of the most important biological factors that control the living coverage of algae. Sammarco et al. (1973) hypothesized that sea urchins may play a significant role in controlling the community structure of sessile epibenthic macroinvertebrates in the shallowest zones of coral reefs. In the present study we have found that grazing activity by sea urchins on algae is among the most important factors regulating and controlling living coverage of algae (Benayahu \& Loya, in preparation). It is suggested that the high diversity of benthic algae (Benayahu, 1975) in the shallow portions of the reefs of Eilat, might be largely possible due to grazing activity of sea urchins and herbivore fishes, which prevent space monopolization by algae.

Some species of soft corals have been observed to form small-scale aggregations in shallow water and thus, to create local monopolization, such as Sinularia sp., Sarcophyton glaucum and Lobopbytum pauciflorum (Tables 6 and 7). This phenomenon may be due to their rapid growth as suggested by Fishelson (1970, 1973b), Maragos (1974b) and Schuhmacher (1974). At present, no quantitative data exists in the literature concerning growth rates of sott corals, as well as data concerning their competitive interactions with other benthic organisms. These lines of research are now under intensive study on the coral reefs of Eilat.

Maragos (1974a) has suggested that predation and competition for space may periodically disrupt the continued development of some corals resulting in a community which is more patchy in abundance. It seems that such factors may account for the observed community structure pattern of soft corals at the reefs of Eilat (Tables 6 and 7). The rather similar pattern of living coverage of stony corals in the upper fore-reef zones, at the various localities (Fig. 5), may be a result of lack of major physical disturbances as suggested by Loya (1976). The low living coverage of algae in these zones might be due to lower illumination levels, which largely control algal vegetation.

The coexistence of stony corals, soft corals and algae in all the areas studied may indicate a lack of competitive dominance by either one of these components. Nevertheless, it is suggested that the observed patterns of space utilization might also result from varied competitive abilities of different species, in different environmental 
regimes. It is of great importance to have a better knowledge of the intraspecific and interspecific competitive hierarchy of the different species among the components studied, in order to have a better understanding of the mechanisms that determine space partitioning on a coral reef.

Acknowledgements. We are grateful to Prof. L. Fishelson, Department of Zoology, Tel Aviv University, for his useful suggestions and criticism. We thank Dr. Y. Lipkin, Department of Botony, Tel Aviv University, for his comments and identification of the algal collection. Special thanks are due to Dr. J. Verseveldt, Zwolle, The Netherlands, for identifying the soft corals. We wish to adknowledge the work of Mr. A. Shoob for the photographs, Mr. Z. Shepher for the illustrations, and Ms. C. Papier for typing the manuscript. We are most grateful to the M. B. L. personnel at Eilat and the field school of Eilat for their kind hospitality. We would like to warmly thank Mr. Y. Shlesinger and Mr. B. Rinkevich for diving assistance and friendship. - This paper is part of a thesis submitted by Y. Benayahu to the Department of Zoology, Tel Aviv University, in partial fulfillment of the requirements for the M. Sc. Degree. Research was supported by the United States-Israel Binational Science Foundation (BSF), Jerusalem, Israel.

\section{LITERATURE CITED}

Bakus, G. J., 1972. Effects of the feeding habits of coral reef fishes on benthic biota. In: Proceedings of the 1st international symposium on corals and coral reefs. Ed. by C. Mukundan \& C. S. G. Pillai. The mar. biol. Ass. of India, Cochin, 445-448.

Belk, M. S. \& Belk, D., 1975. An observation of algal colonization on Acropora aspera killed by Acantbaster planci. Hydrobiologia 46, 29-32.

Benayahu, Y., 1975. Quantitative characteristics of community structure of stony corals, soft corals and algae in the northern Gulf of Eilat (Red Sea). M. Sc. thesis, Tel Aviv Univ., 132 pp. (In Hebrew).

Dahl, A. L., 1972. Ecology and community structure of some tropical reef algae in Samoa. In: Proceedings of the international Seaweed Symp. Ed. by K. Nisizawa. Univ. Tokyo Press, Tokyo, 7, 36-39.

- 1974. The structure and dynamics of benthic algae in the coral reef ecosystem. In: Proceedings of the 2 nd international coral reef symposium. Great Barrier Reef Comm., Brisbane, 1, 21-23.

Dart, J. K. G., 1972. Echinoids, algal lawn and coral recolonization. Nature, Lond., 239, 50-51.

Dayton, P. K., 1971. Competition, disturbance and community organization: the provision and subsequent utilization of space in a rocky intertidal community. Ecol. Monogr. 41, 351-389.

- 1972. Dispersion, dispersal and persistence of the annual intertidal alga Postelsia palmaeformis Ruprecht. Ecology 54, 433-438.

Doty, M. S., 1974. Coral reef roles played by reef living algae. In: Proceedings of the 2 nd international coral reef symposium. Great Barrier Reef Comm., Brisbane, 1, 27-33.

Faure, G., 1974. Morphology and bionomy of the coral reef discontinuities in Rodriguez Island. In: Proceedings of the 2nd international coral reef symposium. Great Barrier Reef Comm., Brisbane, 2, 161-172.

Fishelson, L., 1970. Littoral fauna of the Red Sea: the population of nonscleractinian anthozoans of shallow waters of the Red Sea (Eilat). Mar. Biol. 6, 106-116.

- 1973a. Ecology of coral reefs in the Gulf of Aqaba (Red Sea) influenced by pollution. Oecologia 12, 55-67.

- 1973b. Ecological and biological phenomena influencing coral species composition on the reef table at Eilat (Gulf of Aqaba, Red Sea). Mar. Biol. 19, 183-196. 
Goldberg, W. M., 1973. The ecology of the coral octocoral communities off the southeast Florida coast. Geomorphology, species composition and zonation. Bull. mar. Sci. 23, $465-488$.

Hoek, C. van den, Cortel-Breeman, A. M. \& Wanders, J. B. W., 1975. Algal zonation in the fringing coral reef of Curacao, Netherlands, in relation to zonation of corals and gorgonians. Aquat. Bot. 1, 269-308.

Kinsey, D. W. \& Domm, A., 1974. Effect of fertilization on a coral reef environment primary production studies. In: Proceedings of the $2 \mathrm{nd}$ international coral reef symposium. Great Barrier Reef Comm., Brisbane, 1, 49-66.

Kinzie, R., 1973. The zonation of West Indian gorgonians. Bull. mar. Sci. 23, 93-155.

Klunzinger, C. B., 1877. Die Korallthiere des Rothen Meeres 1. Theil: Die Alcyonarien und Malacodermen. Gutmann, Berlin, 98 pp.

Kükenthal, W., 1913. Alcyonaria des Rothen Meeres. Expeditionen S.M. Schiff "Pola" in das Rotes Meer. Denkschr. Akad. Wiss., Wien (Math.-nat. Kl.) 89, 1-33.

Lang, J., 1971. Interspecific aggression by scleractinian corals. 1 . The rediscovery of Scolymia cubensis (Milne Edwards \& Haine). Bull. mar. Sci. 21, 952-959.

- 1973. Interspecific aggression by scleractinian corals. 2 . Why the race is not only the swift? Bull. mar. Sci. 23, 260-279.

Laxton, J. H. \& Stablum, W. J., 1974. Sample design for quantitative estimation of sedentary organisms of coral reefs. Biol. J. Linn. Soc. 6, 1-18.

Littler, M. M., 1973. The population and community structure of Hawaiian fringing-reef curstose Corallinaceae (Rhodophyta, Crytonemiales). J. exp. mar. Biol. Ecol. 11, 103-120.

- \& Doty, M. S., 1975. Ecological components structuring the seaward edges of tropical Pacific reefs: The distribution, communities and productivity of Protolithon. J. Ecol. 63, 117-129.

Loya, Y., 1972. Community structure and species diversity of hermatypic corals at Eilat, Red Sea. Mar. Biol. 13, 100-123.

- 1975. Possible effects of water pollution on the community structure of Red Sea corals. Mar. Biol. 29, 117-185.

- 1976. Recolonization of Red Sea corals affected by natural catasthrophes and man made perturbations. Ecology 57, 278-289.

- \& Slobodkin, L. B., 1971. The coral reefs of Eilat (Gulf of Eilat, Red Sea). Symp. zool. Soc. Lond. 28, 117-139.

Maragos, J. E., 1972. A study of the ecology of Hawaiian reef corals. Ph. D. thesis, Univ. of Hawaii, Honolulu, 292 pp.

- 1974a. Reef corals of Fanning Island. Pacif. Sci. 28, 247-255.

- 1974b. Coral communities on a seaward reef slope, Fanning Island. Pacif. Sci. 28, 257-278.

Mergner, H. \& Schuhmacher, H., 1974. Morphologie, Okologie und Zonierung von Korallenriffen bei Aqaba (Golf von Aqaba, Rotes Meer). Helgoländer wiss. Meeresunters. 24, 307-326.

Muscatine, L., 1974. Endosymbiosis of cnidarians and algae. In: Coelenterate biology. Ed. by L. Muscatine \& H. M. Lenhoff. Acad. Press, New York, 359-389.

Nishihira, M. \& Yamazato, K., 1974. Human interference with the coral reef community and Acanthaster infestation of Okinawa. Proceedings of the 2 nd international coral reef symposium. Great Barrier Reef Comm., Brisbane, 1, 577-590.

Odum, H. T. \& Odum, E. P., 1955. Trophic structure and productivity of a windward coral reef community on Eniwetok Atoll. Ecol. Monogr. 25, 291-320.

Ogden, J. C., 1976. Some aspects of herbivore-plant relationships on Carribean reefs and seagrass beds. Aquat. Bot. 2, 103-116.

Opresko, D. M., 1973. Abundance and distribution of shallow water gorgonians in the area of Miami, Florida. Bull. mar. Sci. 23, 535-558.

Ott, B., 1975. Community patterns on a submerged barrier reef at Barbados, West Indies. Int. Revue ges. Hydrobiol. 60, 719-736.

Porter, J. W., 1972a. Patterns of species diversity in Carribbean reef corals. Ecology 53, $745-748$. 
- 1972b. Predation by Acanthaster and its effect on coral species diversity. Am. Nat. 106, 487-492.

- 1974. Community structure of coral reefs on opposite sides of the Isthmus of Panama. Science, N. Y., 186, 543-545.

Preston, E. M. \& Preston, J. L., 1975. Ecological structure in a West Indian Gorgonian fauna. Bull. mar. Sci. 25, 248-258.

Randall, J. E., 1961. Overgrazing of algae by herbivorous marine fishes. Ecology 42, 812.

- 1973. Coral reef recovery following extensive damage by the "Crown of Thorns" starfish, Acanthaster planci (L.). Publs Seto mar. biol. Lab. 20, 469-482.

Sale, P. F., 1974. Overlap in resource use and interspecific competition, Oecologia 17, 245-256.

Sammarco, P. W., Levinton, J. S. \& Ogden, J. C., 1973. Grazing and control of coral reef community structure by Diadema antillarum Philippi (Echinodermata, Echinoidea): A preliminary study. J. mar. Res. 32, 47-53.

Schuhmacher, H., 1974. On the conditions accompanying the first settlement of corals on artificial reefs with special reference to the influence of grazing sea urchins (Eilat, Red Sea). In: Proceeding of the 2nd international coral reef symposium. Great Barrier Reef Comm., Brisbane, 1, 257-267.

- 1975. Die Rolle der Weichkorallen (Alcyonacea, Octocorallia) innerhalb der Riffbiozönosen des Roten Meeres und des australischen Großen Barrier-Riffs. Verh. dt. zool. Ges. 67, $380-384$.

Tsuda, R. T. \& Kami, H. T., 1973. Algal succession on artificial reefs in the marine lagoon environment in Guam. J. Phycol. 9, 260-264.

Veron, J. E. N., How, R. A., Done, T. J., Zell, L. D., Dodkin, M. J. \& Farrell, A. F. O., 1974. Corals of the Solitary Islands, central New South Wales. Aust. J. mar. Freshwat. Res. 25, 193-208.

Verseveldt, J., 1965. Report on the Octocorallia (Stolonifera and Aleyonacea) of the Israel South Red Sea Expedition 1962, with notes on other collection from the Red Sea. Bull. Sea Fish. Res. Stn Israel, 16, 28-48.

- 1969. A new species of the genus Anthelia (Octocorallia: Alcyonacea) from the Gulf of Aqaba (Red Sea). Israel. J. Zool. 18, 325-327.

- 1970a. A new species of Sinularia (Octocorallia, Alcyonacea) from Madagascar. Israel. J. Zool. 19, 165-168.

- 1970b. Report on some Octocorallia (Alcyonacea) from the Northern Red Sea. Israel. J. Zool. 19, 209-229.

- 1971. Octocorallia from North western Madagascar (part II). Zool. Verh., Leiden 117, $1-73$.

- 1974. Alcyonacea (Octocorallia) from the Red Sea, with a discussion of a new Sinularia species from Ceylon. Israel. J. Zool. 23, 1-37.

- \& Cohen, J., 1971. Some new species of Octocorallia from the Gulf of Eliat (Red Sea). Israel. J. Zool. 20, 53-67.

Vine, P. J., 1974. Effects of algal grazing and aggressive behaviour of the Pomacentrus lividus and Acanthurus sobal on coral reef ecology. Mar. Biol. 24, 131-136.

First author's address: Y. Benayahu Department of Zoology

Tel Aviv University

Tel Aviv

Israel 